DOI https://doi.org/10.18551/rjoas.2016-12.26

\title{
THE EFFECTS OF SERVICE QUALITY AND CORPORATE REBRANDING ON BRAND IMAGE, CUSTOMER SATISFACTION, BRAND EQUITY AND CUSTOMER LOYALTY: STUDY IN ADVERTISING COMPANY AT TVONE
}

\author{
Chaniago Aspizain \\ Business Administration Program, Politeknik LP3I, Jakarta, Indonesia \\ E-mail: aspizainchaniago@yahoo.com
}

\begin{abstract}
The purpose of this study was to analyze the effects of service quality on brand image, service quality on customer satisfaction, service quality on brand equity, service quality on customer loyalty, corporate rebranding on brand image, corporate rebranding on customer satisfaction, corporate rebranding on brand equity, brand image on customer satisfaction, corporate rebranding on customer loyalty, brand image on brand equity, brand image on customer loyalty, customer satisfaction on customer loyalty, brand equity on customer loyalty. The population of this study consisted of loyal 173 corporate advertisers to tvOne an Indonesian national television company. The sample for this study was set as many as 173 , but only 144 respondents who returned the feedback as part of the study. The 144 data were analyzed by using descriptive and inferential analysis of SEM. The research has proven that (1) the service quality significantly affects the brand image; (2) the service quality significantly influence the customer satisfaction; (3) the service quality significantly affects the brand equity; (4) the service quality significantly affects the customer loyalty; (5) the corporate rebranding has significant effects on the brand image; (6) the corporate rebranding has no significant effect on the customer satisfaction; (7) the corporate rebranding has no significant effect on brand equity; (8) the corporate rebranding has no significant effect on the customer loyalty; (9) the brand image has significant effect on the customer satisfaction; (10) the brand image has significant effects on the brand equity; (11) the brand image does not have significant effects on the customer loyalty; (12) significant effects from the customer satisfaction on customer loyalty; and (13) significant effects of the brand equity on the customer loyalty.
\end{abstract}

\section{KEY WORDS}

Service quality, corporate rebranding, brand image, costumer satisfaction, brand equity, costumer loyalty.

The development of today's business world has increasingly been very competitive, especially in the increase fulfillment towards the human needs. As the implication, the role of marketing strategy is becoming increasingly important as the human needs might be dynamic in accordance with the development so that the marketers must be sensitive in understanding any changes on the tastes of the consumers. The marketing concept is a business philosophy that states that the satisfaction of the customer needs is a prerequisite for economic and social viability of the company (Basu, 2001). The marketing concept holds that the key to realizing the goals of the organization lies in the ability of the organization in creating, delivering and communicating customer value to the target market more effectively compared to the competitors.

The vast development of the market has prompted the companies to find the gap to increase the customer loyalty as reflected in the company achieved profits (Fornel, 1992). Such strategies in order to gain loyal customers are also essential to create a sustainable competitive advantage (Roberts et al, 2003). In business, loyal customers are important assets to the company as this can be understood from the characteristics, as revealed by Griffin (2002) that the the characteristics of loyal customers include making repeat purchases on a regular basis, inter-line purchase of products and services, referring to others and showing resilience against the temptation of competitors. Loyalty is defined as a behavior 
that is expected of a product or service, including the possibility of further purchases or changes to service agreements and how likely customers will switch to another brand or another service provider (Schnaars, 1998). Oliver (1999) stated that customer loyalty as a deeply-held commitment to rebuy an item or come back to the service provider consistently in the future, resulting in the repeated purchase of the brand or same brand set. Loyalty can be achieved if the costumers are satisfied with the brand or the level of service quality received and intended to continue the relationship.

The relationship of service quality to the excellence of sources such as customer satisfaction and customer loyalty as stated by Liao (2009) that the service quality has may affect on the customer satisfaction and customer satisfaction has impacts to the customer loyalty. Saura, et al. (2008) also supports the direct effect of service quality and positive impact on customer satisfaction, customer satisfaction as well as direct positive effect on loyalty. Oliver (1997) stated that customer satisfaction is the response from the customer fulfillment (of their needs). Zethaml (2000) stated that the service quality and customer satisfaction are determined by the same attributes that good quality service may increase the customer satisfaction and loyalty, and thus it might meet the objectives of the company in the end.

According to Kertajaya (2010), the company must always develop if it is to last in the long term, which is not growing at the expense of all the costs but still make a profit growth, to grow and at the same time make a profit one way is to innovate. There are three types of innovations that can be selected by the company, namely minor invasion, moderate innovation, and major innovation. Minor innovation is innovation that aims to be better than the competitors, while moderate innovation is innovation that aims to improve the relationship with customers through new products or services, while the highest innovation is major innovation in which the company radically may change the positioning in the market, change and alter brand differentiation. The changes in the competitive position and changes in the external environment may cause the companies conduct corporate rebranding (Kaikati \& Andrew, 2003). Muzellec and Lambkin (2006) define the corporate rebranding as the creation of a name, term, symbol, design or a combination of these aspects that are new to a brand that has been established with the aim to develop a new and distinct position in the minds of stakeholders, including customers and competitors. Gauraf (2008) states that the corporate rebranding is a powerful and reliable tool in changing the corporate identity, logos, slogans and advertising to deliver a new brand image; rebranding is a good choice to change public perception by giving the new brand image of the previous brand, and the corporate rebranding is established by the company for various reasons, namely the market repositioning, to change the name of the foreign-affiliated as the prohibition by the authority, to adjust to a new design, the change of ownership or management and attempts to repair the damaged or unfavorable image.

In the disclosure condition of channel tvOne set as the object to be studied based on the presence of symptoms and problems of innovation in relation to minor, moderate and major innovations to the service quality and corporate rebranding, where the feasibility of objects based on the channel tvOne as the service changes since the corporate rebranding from Lativi into tvOne, so it was relevant to be the object of this research. The phenomenon of tvOne rebranding was significant and becomes the target of some empirical studies of rebranding and service quality to the brand image, customer satisfaction, brand equity, and customer loyalty. The previous empirical studies have been conucted by Liao (2009) as the framework to examine the core of the biggest factors that may affect customer loyalty, to test the effect of the variables including the service quality to the perception of values, trusts, customer satisfaction and customer loyalty.

In the research by Liao (2009), there were no brand-oriented variables to attest the biggest factors that may affect the customer loyalty, the orientarion was not enough just to discuss solely by approaching the service quality, the perception of values and trusts in order to achieve customer satisfaction and customer loyalty, but it was supposed to be also associated with various other variables including the brand-oriented variables. This research study was to accommodate the three variables by Liao (2009), namely service quality, 
customer satisfaction and customer loyalty. A research by Lo, L.K. et al (2010) also confirms the positive influence between service quality, customer satisfaction and customer loyalty, a research by Mokhtar, et al (2011) also supports that the quality of service and customer satisfaction significantly affect the level of customer loyalty, research by Mohsan (2011) also supports that customer satisfaction is positively correlated with the customer loyalty, research by Jahanshashi, et al (2011) also supports that the service quality has a positive effect on the customer satisfaction and customer loyalty.

Customer loyalty and customer satisfaction are creatsed as the presence of a lot of brand image, positive strength of brand strength, and to be supported by previous studies related to the customer and the brand. Strong and qualited brand tend to have a good image, which also has a good quality of service; the brand is able to translate the quality of service and customer satisfaction to customers' fanaticism to the brand. Teck, et al. (2012) showed that the quality of service may affect the brand in other words the relationship of service quality on brand image significantly, the results of a study by Tu, Y. et al (2012) found that the brand image may significantly affect customer satisfaction and customer loyalty, the results of the research conducted by Hossien (2011) similarly found that the brand image influences the brand equity. Research by Hong, YH (2009) showed a positive effect of service quality on brand equity, similar research by Omar and Ali (2010) found a positive relationship of brand equity to customer loyalty, to ensure that customer loyalty can be created on any brand, and not just the brands that are already big and famous, but the needs of assurance against any brand is carried through the rearrangement and recreation of the brand. You can bet every brand is really strong and has a positive image and then with readiness good quality service then we will get customer satisfaction ultimately gain the loyalty of customers, in other words that the research by Liao (2009) needs to be added and is equipped with a brand-oriented approach variable to the brand. Variables included in this study were adopted the corporate rebranding of research Goi Tea May (2009) who found that the rebranding may affect brand equity, further Petburikul (2009) stated that there is a rebranding of the brand equity, the research supports Tea May Go (2009) and Petburikul (2009), related to rebranding variable, it was reinforced also by the research journal by Plewa et al. (2009) who showed that the rebranding may affect customer satisfaction.

From the summary of the empirical researches above, it may be summed up that there are some variables that may affect each other, namely: the service quality on the customer satisfaction, the service quality on the brand image, the service quality on the brand equity and relationships among variables of the corporate rebranding to customer satisfaction and corporate rebranding to the brand equity. The relationships among variables of brand image on customer satisfaction and brand image on brand equity, as well as the relationship between the variables of brand image on customer loyalty, customer satisfaction to customer loyalty, brand equity to customer loyalty. The effects among these variables will answer whether the quality of services and corporate rebranding affect brand image, customer satisfaction and customer loyalty.

The main research problems of this study can be formulated as follows whether the quality of service and corporate rebranding affect brand image, customer satisfaction, brand equity and customer loyalty. The main problem of the study will be outlined in the research questions formulated: (1) Does the quality of service significantly affect the brand image? (2) Does the quality of services significantly affect customer satisfaction? (3) Does the quality of service significantly affect brand equity? (4) Does the quality of service significantly affect customer loyalty? (5) Does corporate rebranding have significant effect on brand image? (6) Does corporate rebranding have significant effect on customer satisfaction? (7) Does corporate rebranding have significant effect on brand equity? (8) Does corporate rebranding have significant effect on customer loyalty? (9) Does brand image have significant effect on customer satisfaction? (10) Does the brand image have significant effect on brand equity? (11) Does brand image have significant effect on customer loyalty? (12) Does the customer satisfaction have significant effect on customer loyalty? (13) Does brand equity have significant effect on customer loyalty? The primary objective of this study was to analyze and 
explain the effects of service quality and corporate rebranding of the brand image, customer satisfaction, and brand equity and customer loyalty.

\section{METHODS OF RESEARCH}

The samples of this study were companies as advertisers on national TV channel tvOne, with a survey instrument using Likert Scale (scale 1-5), from strongly agree was given a score (5), to strongly disagree given a score (1). The instrument consisted of 34 items of service quality, corporate rebranding, brand image, customer satisfaction, brand equity, and customer loyalty. Before the questionnaires completed, a pretest was conducted involving 20 companies of advertisers on the national television (channel) tvOne. The survey was conducted from July to August 2013. This study used a population sample or all members of the sample population is used as a research and any organization (company) advertisers on tvOne represented by the marketing manager or marketing director as respondents. Census methods are all members of the population to become the sample (Singarimbun \& Efendi, 1996). Reasons for using the census as a method of data collection techniques was because the population could reach as many as 173 that are located in Jakarta and surrounding areas that actualize opinion of Gay and Diehl (1992), the more samples that are taken will be more representative and the results can be generalized, however only 144 ot of 173 samples that returned the inputs, or in other words, the effective rate (response rate) of the respondents was $83 \%$.

\section{RESULTS AND DISCUSSION}

For the analysis of the validity and reliability based on test results that all values Cronbach's alpha $(\alpha)$ of each variable was 0.899 for the quality of service, 0.828 for the corporate rebranding, 0.805 for the brand image, 0,877 for the customer satisfaction, 0.623 for the brand equity and 0.833 for customer loyalty; all of them were above 0.60 so that it could be said that all the questions on the six variables studied are reliable, so the research instrument that measures six variables wre valid and reliable, and measurement data using a questionnaire feasible. Confirmatory Factor Analysis (CFA) in this study showed significant whole construct, each indicator was jointly presenting a unidimensional, precise, consistent and dominant indicators, forming the construct under investigation in all variables.

The conceptual framework of this study can be said as fit if it is supported by the theoretical model the empirical data. In line with the results of SEM, that the goodness of fit test results was to determine whether a full model hypothesized model had the support of empirical data, shown in Table 1.

Table 1 - Test results through Goodness of Fit Full model

\begin{tabular}{|c|c|c|c|c|}
\hline No & Goodness-of-Fit index & Cut-Off Value & Results & Note \\
\hline 1 & Significance Probability & $\geq 0, .05$ & 0.101 & Significant \\
\hline \multicolumn{5}{|c|}{ Absolute Fit Measures } \\
\hline 2 & $\mathrm{X}^{2}$ - Chi-square & $\mathrm{X}^{2}$ Table (df 263)=319.276 & 298.039 & Significant \\
\hline 3 & RMSEA & $\leq 0.08$ & 0.072 & Significant \\
\hline 4 & GFI & $\geq 0.90$ & 0.956 & Significant \\
\hline \multicolumn{7}{|c|}{ Incremental Fit Measures } \\
\hline 5 & TLI & $\geq 0.95$ & 0.971 & Significant \\
\hline 6 & CFI & $\geq 0.95$ & 0.967 & Significant \\
\hline \multicolumn{7}{|c|}{ Parsimonious Fit Measures } \\
\hline 7 & AGFI & $\geq 0.90$ & 0.962 & Significant \\
\hline 8 & CMIN/DF & $\leq 2.00$ & 1.133 & Significant \\
\hline
\end{tabular}

The test results through goodness of fit full model to investigate whether the hypothesis model is supported by the empirical data, as shown on Figure 1. 


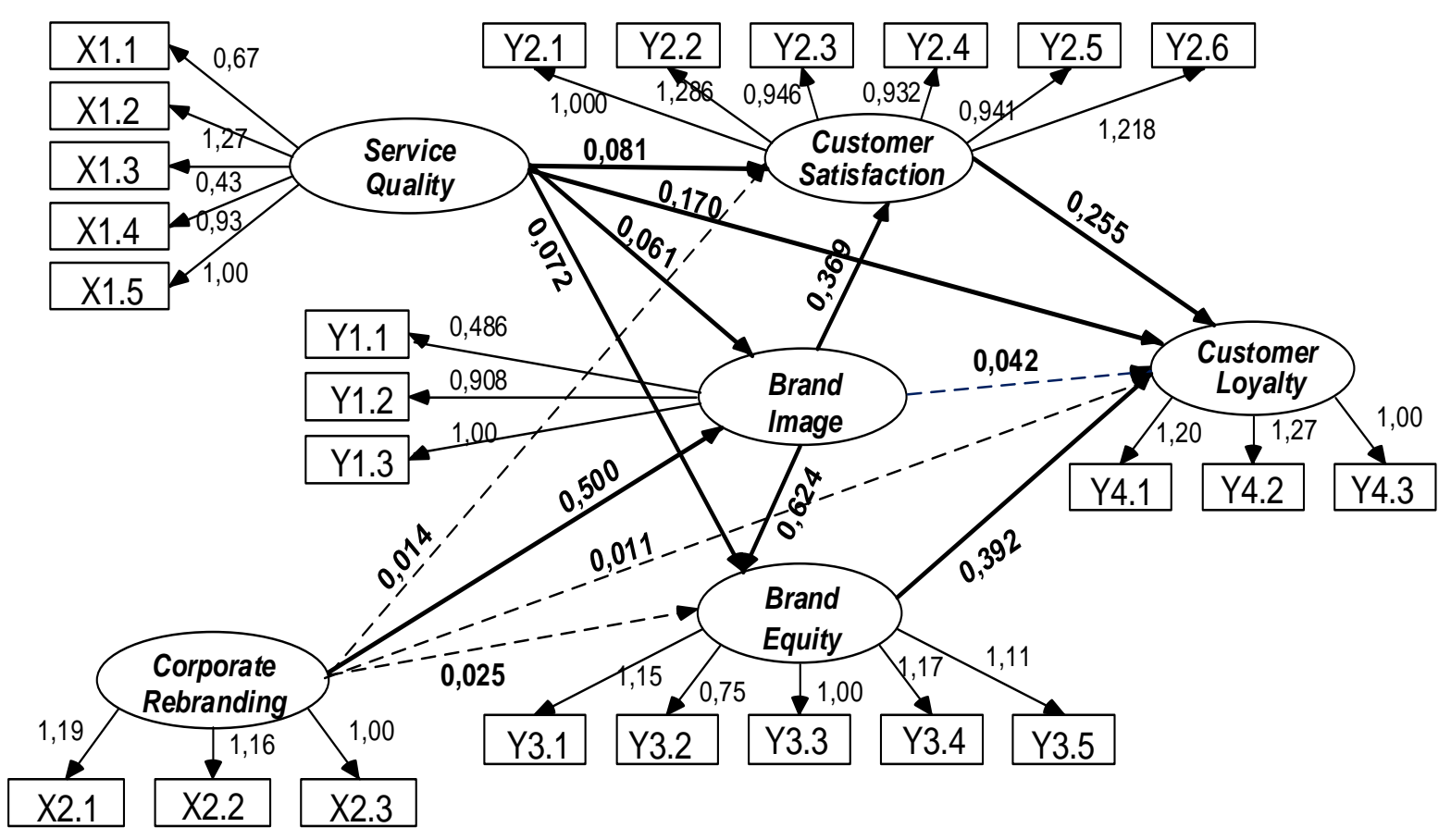

\section{: Significant \\ ---- : Non Significant}

Figure 1 - Path Diagram of SEM Result

From the test results, it appears that there were 9 paths that indicate significant causal relationships; it is seen from the value of significance ( $p$-value) which was less than $5 \%$, while the other four paths show the causal relationships which were not significant, it can be seen from the value of significance ( $p$-value) of greater than $5 \%$, namely the corporate rebranding to customer satisfaction, the corporate rebranding to the brand equity, the corporate rebranding on the customer loyalty and the brand image to the customer loyalty. Structural models of SEM Results Direct Effect can be seen in Table 2.

Table 2 - Structural Model for SEM Results Direct Effect

\begin{tabular}{|c|l|c|c|c|}
\hline Hypotheses & \multicolumn{1}{|c|}{ Relationships among variables } & Standardize & $P$-Value & Note \\
\hline 1 & Service quality (X1) to Brand Image (Y1) & 0.147 & 0.034 & Significant \\
\hline 2 & Service quality (X1) to Kepuasan Pelanggan (Y2) & 0.235 & 0.011 & Significant \\
\hline 3 & Service quality (X1) to Brand Equity (Y3) & 0.193 & 0.027 & Significant \\
\hline 4 & Service quality $(\mathrm{X} 1$ to Cosntumer Loyalty (Y4) & 0.471 & 0.000 & Significant \\
\hline 5 & Corporate Rebranding X2) ke Brand Image (Y1) & 0.488 & 0.000 & Significant \\
\hline 6 & Corporate Rebranding (X2) to Costumer satisfaction (Y2) & 0.016 & 0.883 & Not Significant \\
\hline 7 & Corporate Rebranding (X2) to Brand Equity (Y3) & 0.027 & 0.804 & Not Significant \\
\hline 8 & Corporate Rebranding (X2) to Costumer Loyalty (Y4) & 0.012 & 0.884 & Not Significant \\
\hline 9 & Brand Image (Y1) to Costumer Satisfaction (Y2) & 0.441 & 0.000 & Significant \\
\hline 10 & Brand Image (Y1) to Brand Equity (Y3) & 0.688 & 0.000 & Significant \\
\hline 11 & Brand Image (Y1) to Costumer Loyalty (Y4) & 0.048 & 0.735 & Not Significant \\
\hline 12 & Costumer satisfaction (Y2) to Costuer loyalty (Y4) & 0.243 & 0.005 & Significant \\
\hline 13 & Brand Equity (Y3) to Costumer loyalty (Y4) & 0.406 & 0.005 & Significant \\
\hline
\end{tabular}

Note: $(p$-Value < 0.05).

The hypotheses proposed in this study were 13 (thirteen) hypothesese. Based on the results of the study indicate that there were 9 (nine) hypotheses that are accepted and 4 (four) hypotheses that are rejected. The results of hypothesis testing can be described as follows.

$\mathrm{H} 1, \mathrm{H} 2, \mathrm{H} 3$ and $\mathrm{H} 4$ showed a significant effect between the service quality on the brand image, customer satisfaction, brand equity, and customer loyalty. The results of this 
study support the research by Liao (2009) the quality of services significantly affect the customer satisfaction, customer loyalty. Teck et al. (2012) which also suggests a significant impact on the quality of service to the brand image. The results of this study also supports researches by Mokhtar et al. (2011), Jahanshashi et al. (2011), Lo et al. (2010) which suggest that the quality of service significantly impacts the customer satisfaction. The results of this study support the research by Hong, YH (2009) which suggests that the quality of service has significant impacts to the brand equity, explaining that the very strong influence of service quality effect to the brand equity.

$\mathrm{H} 5, \mathrm{H} 6, \mathrm{H} 7$, and $\mathrm{H} 8$ showed that corporate rebranding has a significant effect on the brand image, however no significant effects on customer satisfaction, brand equity, and customer loyalty. The results of this study support the research by Bamiduro and Aremu (2012) which asserts the influence of the corporate rebranding to the brand image. These results are different with the studies by Plewa et al (2010) that argued corporate rebranding has a significant impact to the customer satisfaction. The results of this study are also different with Petburikal's study (2009) which suggests that corporate rebranding has a significant impact to the brand equity. The results of this study are also different with the study by Teh (2009) that suggests the corporate rebranding has a significant impact on the brand equity. The results of this study support the research by Tevi (2013) which states that to determine the impact of rebranding on customer loyalty with rebranding findings did not significantly affect the attitude of the customer in choosing the brand, thus that customers are not loyal to a particular brand.

$\mathrm{H} 9, \mathrm{H} 10$, and $\mathrm{H} 11$ showed a significant effect of the brand image on the customer satisfaction, brand equity, and customer loyalty. The results of this study support the research by Tu, Y et al. (2012) suggested that the brand image significantly impact the customer satisfaction. Brand image of the company affects significantly on the customer satisfaction and customer loyalty. Customer satisfaction, in other words, has a strong impact to the customer loyalty towards the products. The results of this study support the research by Hossien (2011) that suggests that the brand image has a significant impact to the brand equity. Brand image significantly affects the brand equity, where the brand loyalty and brand image influence brand equity, brand loyalty, and brand image as mediation in support of the brand equity. The consumer perceptions towards the brand equity dimensions may affect the assessment of the overall brand equity. These results are meanwhile different with the studies by Tu et al. (2012) that asserted there was a significant impact of brand image on customer loyalty.

$\mathrm{H} 12$ showed that costumer satisfaction has a significant effect on the costumer loyalty. This result is in line with the research by Mohsan (2011), Mokhtar et al (2011), Tu et al (2012), Lo et al (2010), Jahanshashi et al (2011), Liao (2009) that all support the idea of prominent positive relationship between consumer satisfaction and costumer loyalty.

$\mathrm{H} 13$ stated that brand equity has a significant effect on customer loyalty. The results of this study support the research of Omar and Ali (2010) that connects the brand equity to customer loyalty.

Table 3 - Structural model of SEM results indirect effect

\begin{tabular}{|c|c|c|c|c|}
\hline Indirect effects & \multicolumn{2}{|c|}{ Direct effect coefficient } & $\begin{array}{c}\text { Indirect effect } \\
\text { coefficient }\end{array}$ & Note \\
\hline $\mathrm{X} 1 \rightarrow \mathrm{Y} 1 \rightarrow \mathrm{Y} 2$ & $\mathrm{X} 1 \rightarrow \mathrm{Y} 1=0.147$ & $\mathrm{Y} 1 \rightarrow \mathrm{Y} 2=0.441$ & 0.065 & Significant \\
\hline $\mathrm{X} 1 \rightarrow \mathrm{Y} 1 \rightarrow \mathrm{Y} 3$ & $\mathrm{X} 1 \rightarrow \mathrm{Y} 1=0.147$ & $\mathrm{Y} 1 \rightarrow \mathrm{Y} 3=0.688$ & 0.101 & Significant \\
\hline $\mathrm{X} 1 \rightarrow \mathrm{Y} 1 \rightarrow \mathrm{Y} 4$ & $\mathrm{X} 1 \rightarrow \mathrm{Y} 1=0.147$ & $\mathrm{Y} 1 \rightarrow \mathrm{Y} 4=0.048$ & 0.007 & Significant \\
\hline $\mathrm{X} 1 \rightarrow \mathrm{Y} 2 \rightarrow \mathrm{Y} 4$ & $\mathrm{X} 1 \rightarrow \mathrm{Y} 2=0.235$ & $\mathrm{Y} 2 \rightarrow \mathrm{Y} 4=0.243$ & 0.057 & Significant \\
\hline $\mathrm{X} 1 \rightarrow \mathrm{Y} 3 \rightarrow \mathrm{Y} 4$ & $\mathrm{X} 1 \rightarrow \mathrm{Y} 3=0.193$ & $\mathrm{Y} 3 \rightarrow \mathrm{Y} 4=0.406$ & 0.078 & Significant \\
\hline $\mathrm{X} 2 \rightarrow \mathrm{Y} 1 \rightarrow \mathrm{Y} 2$ & $\mathrm{X} 2 \rightarrow \mathrm{Y} 1=0.488$ & $\mathrm{Y} 1 \rightarrow \mathrm{Y} 2=0.441$ & 0.215 & Significant \\
\hline $\mathrm{X} 2 \rightarrow \mathrm{Y} 1 \rightarrow \mathrm{Y} 3$ & $\mathrm{X} 2 \rightarrow \mathrm{Y} 1=0.488$ & $\mathrm{Y} 1 \rightarrow \mathrm{Y} 3=0.688$ & 0.335 & Not Significant \\
\hline $\mathrm{X} 2 \rightarrow \mathrm{Y} 1 \rightarrow \mathrm{Y} 4$ & $\mathrm{X} 2 \rightarrow \mathrm{Y} 1=0.488$ & $\mathrm{Y} 1 \rightarrow \mathrm{Y} 4=0.048$ & 0.023 & Not Significant \\
\hline $\mathrm{X} 2 \rightarrow \mathrm{Y} 2 \rightarrow \mathrm{Y} 4$ & $\mathrm{X} 2 \rightarrow \mathrm{Y} 2=0.016$ & $\mathrm{Y} 2 \rightarrow \mathrm{Y} 4=0.243$ & 0.004 & \\
\hline $\mathrm{X} 2 \rightarrow \mathrm{Y} 3 \rightarrow \mathrm{Y} 4$ & $\mathrm{X} 2 \rightarrow \mathrm{Y} 3=0.027$ & $\mathrm{Y} 3 \rightarrow \mathrm{Y} 4=0.406$ & 0.011 & \\
\hline
\end{tabular}


For the indirect effect, the result is of the multiplication of two of the direct influence. Indirect effect can be declared significant if both significant direct influences that shape the significance. Structural model of SEM results indirect effect can be seen in Table 3.

The implications of service quality are considered as fundamental and thus to assure the management of tvOne to be applied, due to the implementation of corporate rebranding can be excecuted if only it is supported with the optimal quality of service. The implications of corporate rebranding that has been conducted by tvOne will give positive impact if the implementation of maximum service quality is excecuted and ultimately the impact may improve the brand image, customer satisfaction, brand equity and customer loyalty. Implications brand image is very important as an intervening indirect effect that makes customers feel satisfied, as well as to create brand equity and customer loyalty. The implications of customer satisfaction can be employed through the commitment of the management of tvOne in realizing management competence and providing quality assurance services implementation. The implications of brand equity, namely by getting a good image of the management of tvOne through consistent performance of the management that will give positive impact on the brand equity in order to achieve a strong and well-known brand, giving an impact on the loyalty of the advertisers in the television (tvOne).

\section{CONCLUSIONS}

There are some conclusions from this study as follows:

1. Service quality directly affects the brand image. This means that the better quality of service by tvOne, the better the brand image of tvOne, and vice versa.

2. Service quality directly influences the customer satisfaction. This means that the better service quality of tvOne might impact positively to the the customer satisfaction towards tvOne, and vice versa.

3. Quality service has direct effect on the brand equity. This means that the better quality service of tvOne, the better the brand equity of tvOne, and vice versa.

4. Service quality affects the customer loyalty. This means that the better service quality of tvOne might create loyalty within the customers of tvOne, and vice versa.

5. Corporate rebranding has effect on the brand image. This means that if the better corporate rebranding of tvOne, the better the brand image of tvOne, and vice versa.

6. Corporate rebranding has no significant and direct effect on customer satisfaction. This result means that corporate rebranding conducted by tvOne might not enable customer satisfied by the advertisers on the channel. Indirectly, however, the corporate rebranding has significant effect on customer satisfaction in terms of brand image.

7. Corporate rebranding has no significant and direct effect on the brand equity. This result means that corporate rebranding conducted by tvOne might unable to create brand equity directly. Indirectly, however, the corporate rebranding has significant effect on the customer satisfaction in terms of brand image.

8. Corporate rebranding has no significant and direct effect on the customer loyalty. This result means that the corporate rebranding conducted by tvOne might unable to create customer loyalty directly. Indirectly, however, the corporate rebranding has significant effect on the customer loyalty in terms of brand image, customer satisfaction or brand equity.

9. Brand image directly influences the customer satisfaction. This means that the better the brand image of tvOne, the better the customer satisfaction towards the channel, and vice versa.

10. Brand image has direct influence to the brand equity. This means that if tvOne has better brand image, the better the brand equity of tvOne, and vice versa.

11. Brand image has no significant and direct effect on the customer loyalty. This result means that the brand image of tvOne might uable to directly create customer loyalty advertisers on the channel, except through the indirect effect in terms of customer satisfaction or brand equity. 
12. Customer satisfaction directly influences the customer loyalty. This means that if the costumers are satisfied well, the better the customer loyalty towards tvOne, and vice versa.

13. Brand equity has direct effect on the customer loyalty. This means that if the better brand equity of tvOne, the better the customer loyalty towards the channel, and vice versa.

\section{REFERENCES}

1. Bamiduro, J.A. and Aremu, M.A. 2012. Assessment of the Need for and Effectiveness of Re-Branding in Nigeria, International Journal of Management and Administrative Sciences (IJMAS), (ISSN: 2225-7225), Vol. 1, No. 4, January, 2012 (pp. 11-22).

2. Fornell, C. 1992. A National Customer Satisfaction Barometer: The swedish experience. Journal Of Marketing. Vol. 56, no.1, pp. 6-21.

3. Gaurav, K. 2008. Rebranding: Concept, Cases and Applications. The Icfai University Press. Hyderabad.

4. Gay, L.R. and Diehl, P.L. 1992. Research Methods for Business and Management. Journal MacMillan Publishing Company, New York

5. Griffin, J. 2002. Customer loyalty: How to Earn it, How to keep it. New and Revised Edition. McGraw-Hill: Kentucky, Lexington Books. Singapore.

6. Hossien, E. 2011. Determinants of Brand Equity: Offering a Model to Chocolate Industry. World Academy of Science, Engineering and Technology 59.

7. Hong, Y.H. 2009. Effects of Two Types of Service Quality on Brand Equity in China: The Moderating Roles of Satisfaction, Brand Associations, and Brand Loyalty. Journal of Business. Volume 15, Number 2. Kangwon National University South Korea. Seoul.

8. Jahanshani, A.A., Hajizadeh, G.M.A., Mirdhamadi, S.A., Nawaser, K., Khaksar, S.M.S. 2011. Study the Effects of Customer Service and Product Quality on CustomerSatisfaction and Loyalty. Universiti Teknologi Malaysia, Malaysia International Journal of Humanities and Social Science Vol. 1 No. 7.

9. Kaikati, J.G. and Andrew, M. 2003. A rose by any other name: rebranding campaigns that work. Journal of Business Strategy, 24, pp. 17.

10. Kertajaya, H. 2010. Grow With Character, The Model Marketing. Gramedia Pustaka Utama, Jakarta.

11. Liao, N.N.H. 2009. The Pivotal Role of Trust in Customer Loyalty: Empirical Researchon the System Integration Market in Taiwan. Chihlee Institute of Technology, Taipei, TaiwanTsui- chih Wu, Shih Chien University,Taipei, Taiwan The Business Review, Cambridge. Vol. 12 Num. 2. Summer 2009.

12. Lo, L.K., Mahamad, O., Ramayah, T., and Mosahab, R. 2010. The Impact of Service Quality on Customer Loyalty:A Study of Banks in Penang, Malaysia. www.ccsenet.org/ijms International Journal of Marketing Studies Vol. 2 November, No.2.

13. Mohsan, F. 2011. Impact of Customer Satisfaction on Customer Loyalty and Intentions to Switch: Evidence from Banking Sector of Pakistan. Hailey College of Commerce,. International Journal of Business and Social Science Vol.2 September. No.16. University of the Punjab, Pakistan.

14. Mokhtar, S.S.M, Maiyaki, A.A., Noor, N.M. 2011. The Relationship Between Service Quality and Satisfactionon Customer Loyalty in Malaysian Mobile Communication Industry. Universiti Utara Malaysia. School of Doctoral Studies (European Union) Journal. Malaysian.

15. Muzellec, L. and Lambkin, M. 2006. Corporate rebranding: destroying, transferring or creating brand equity. European Journal of Marketing, Vol. 40, No. 7/8, pp. 803-824.

16. Oliver, R.L. 1999. Whence consumer loyalty. Journal of Marketing 63: pp. 33-44.

17. A Behavioral Perspective on the Consumer. McGraw-Hill: New York, 1997.

18. Omar, M. and Ali, M.N.M. 2010. Managing Brand Equity among Langkawi's (SMEs) Independent Hoteliers. International Journal of Marketing Studies, 1(2), pp. 147. 
19. Petburikul, K. 2009. The Impact of Corporate Re-branding on Brand Equityand Firm Performance. Institute of International Studides, Ramkhamhaeng University Bangkok, Thailand. RU. Int. J. vol. 3 (1).

20. Plewa, C., Lu, V., and Veale, R. 2011. The impact of rebranding on club member relationships. Asia Pacific Journal of Marketing and Logistics, 2(23), pp. $222-242$.

21. Roberts, K., Varki, S and Brodie, R. 2003. Measuring the quality of relationships in consumer services: an empirical study. European Journal of Marketing, Vol. 37, No.1/2

22. Saura, I.G., Frances, D. S., Contri, G.B., and Blasco, M.F. 2008. Logistics service quality: a new way to loyalty. Industrial Management \& Data Systems, C No. 5, 650-668.

23. Schnaars. 1998. Marketing Strategy: Customers and Competitions, 2nd edition. Free Press. New York

24. Singarimbun, M. and Efendi, S. 1996. Metode Penelitian Survei, PT. Pustaka LP3ES, Jakarta.

25. Teck, M.T., Tze, W.L., Lee, S.S.W., Ong, B.F.M., and Tan, S. 2012. Consumer-based Brand Equity in the Service Shop. International Journal of Marketing Studies; Vol. 4, No. 4; ISSN 1918-719X E-ISSN 1918-7203.

26. Teh, G.M. 2009. Rebranding of higher educational institutions in Malaysia. International Journal of business and management. Vol. 4, No.9, pp.170-177.

27. Tevi, A.C. 2013. The Effect of Multiple Rebranding on Customer Loyalty in Nigerian Mobile Telephony, School of Media and Communication, Pan African University, Lagos, , Online Published: March 5, 2013. Nigeria.

28. Tu, Y., Wang, C., and Chang, H. 2012. Corporate Brand Image and Customer Satisfaction on Loyalty: An Empirical Study of Starbucks Coffee in Taiwan. Journal of Social and Development Sciences Vol. 3, No. 1, pp. 24-32, Jan (ISSN 2221-1152) Institute of Technology, Taiwan. 